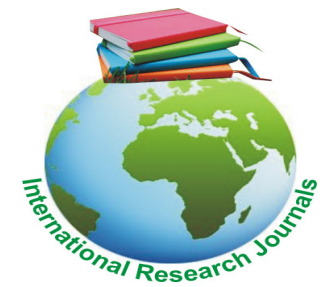

African Journal of Food Science and Technology ((ISSN: 2141-5455) Vol. 5(3) pp. 81-89, March, 2014

DOI: http:/dx.doi.org/10.14303/ajfst.2014.024

Available online @http://www.interesjournals.org/AJFST

Copyright (C2014 International Research Journals

Full Length Research Paper

\title{
Comparison of chemical composition, functional properties and amino acids composition of quality protein maize and common maize (Zea may $L$ )
}

\author{
Abiose Sumbo H. and *lkujenlola A. Victor \\ Department of Food Science and Technology, Obafemi Awolowo University, Ile-Ife, Osun State, Nigeria. \\ *Corresponding authors e-mail: avjenlola@gmail.com; avjenlola@oauife.edu.ng: Tel:+234-8033843674
}

\begin{abstract}
The objective of this study was to determine the chemical composition, functional properties and amino acids profile of Quality Protein Maize (QPM) and compare with Common Maize (CM). The maize grains and maize meal were assessed for physical properties, proximate composition, mineral, functional properties and amino acid profile using standard methods. The results showed that the proximate composition of QPM $9.72 \%$ (protein), $4.85 \%$ (fat), $1.50 \%$ (ash) and $73.98 \%$ (carbohydrate) were within the same range for $\mathrm{CM}$. There was no significant difference $(p>0.05)$ in the proximate composition of the two varieties of maize. The amino acid profile of the QPM was significantly higher $(p<0.05)$ than CM in terms of lysine $(2.64 \mathrm{~g} / 100 \mathrm{~g})$, isoleucine $(2.74 \mathrm{~g} / 100 \mathrm{~g})$, phenylalanine $(4.20 \mathrm{~g} / 100 \mathrm{~g})$. The functional properties of QPM in terms of bulk density, water and oil absorption capacities showed no significantly difference ( $p>0.05$ ) from CM. However, the final viscosity of QPM (267.75 RVU) was significantly lower $(p<0.05)$ than $458.08 \mathrm{RVU}$ of the CM. QPM can be integrated into the family diet and especially in the weaning food formulation for infant where protein energy malnutrition is a serious problem, due to the higher level of the essential amino acids in the available protein of quality protein maize.
\end{abstract}

Keywords: Protein, amino acid, viscosity, physical properties, lysine.

\section{INTRODUCTION}

Maize (Zea mays L.) is an important cereal grain in the world, providing nutrients for humans and animals (FAO, 1992, Vasal et al., 1993). In sub-Saharan Africa, maize is a staple food for an estimated $50 \%$ of the population and it remains the most important agricultural crop for over 70 million farm families worldwide. Of the 22 countries in the world where maize forms the highest percentage of energy in the national diet, 16 are in Africa (Nuss and Tanumihardjo, 2011). Maize is used as human food in the form of tortillas, porridge, popcorn and barbecues and as forage and silage for animals. It is also a good source of industrial products such as starch (Zhang et al., 2012), vitamin (Warman and Havard, 1998), fiber (Pandya and Srinivasan, 2012), oil (Comin et al., 2012), weaning food (Ikujenlola and Fashakin, 2005), porridges (Mburu et al., 2012) and ethanol (Lamsal et al., 2011). Maize kernels are the largest cereal seed weighing $250-300 \mathrm{mg}$ each, they are flat seed due to pressure during growth from adjacent kernels on the cob. The kernels have a blunt crown and pointed conical tip cap (Ihekoronye and Ngoddy, 1985). The kernel contains a complete embryo and all the structural, nutritional and enzymatic functions required for growth and development into a plant (Bressani, 1990). About 50 species exist and consist of different colors, textures and grain shapes and sizes. According to Prassanna et al., (2001) quality protein maize was developed from the convectional opaque -2 maize with modification in the germ-plasm. Like its opaque-2 counterpart, QPM is considered a biofortified food, because its nutritional profile has been improved using conventional breeding techniques. This special type of maize possess almost double the levels of lysine and 
tryptophan which are essential amino acid for monogastric animal including man (Prassana et al, 2001). The aim of this study was to assess the chemical composition, functional properties and amino acids profile of quality protein maize and compare the results with the common maize both grown in Nigeria.

\section{MATERIAL AND METHODS}

The Quality Protein Maize (QPM) Obatampa var. used for this study was supplied by Research Farms, Obafemi Awolowo University, lle - Ife, Nigeria. The common Maize (CM) was supplied by Agricultural Development Project, Owo. Nigeria.

\section{Methods}

\section{Physical and malting properties Assessment}

The physical properties of the maize grains were assessed by adopting the method of A.O.A.C (1990) to evaluate the colour and thousand grain weight. The moisture uptake was determined using the method of Fashakin (1994). The malt yield, germinative capacity and germinative energy were determined using the method of llori et al., (1990).

\section{Production of Quality protein maize meal}

The quality protein maize and common maize grains used for this study were cleaned, sorted and milled according to the method of Houssou and Ayernor (2002). The resulting meal was packaged and kept for further analyses.

\section{Chemical Composition Determination}

Samples and standard solutions were prepared according to the procedures of the AOAC (2004). The proximate composition (protein, fat, ash, crude fibre, moisture and carbohydrate) of the meal was determined as described by A.O.A.C. (2004). Total carbohydrate was determined by difference. The energy content was determined by using the method of Osborne and Voogt (1978) which calculates the energy content using Atwater factor ( $9 \times$ fat $+4 \times$ protein $+4 \times$ carbohydrate) .

The selected mineral elements ( $\mathrm{Na}, \mathrm{Ca}, \mathrm{Mg}, \mathrm{K}, \mathrm{Fe}$ and $\mathrm{Zn}$ ) concentrations were determined from solution obtained from wet digestion of sample ash with mixture of $\mathrm{HCl}$ solution and nitric acid (1:1 v/v) using Alpha 4 Atomic Absorption Spectrophotometer (A.O.A.C. 2004). The phytate was determined using the method of Maga (1982).

\section{Amino acid analysis}

The amino acid composition of the sample was determined according to the method of Spackman et al., (1958) and Kaga et al., (2002). The amino acid analysis was determined at the Department of Zoology, University of Jos, using the High Performance Liquid Chromatography (HPLC) specifically the Technicon TSM (technosequential multisample) analyser for amino acid. The samples were dried to constant weight and defatted. A known weight of the defatted sample was hydrolysed under vacuum with $7 \mathrm{~mL}$ of $6 \mathrm{~N} \mathrm{HCl}$ in a sealed pyrex tube at $105^{\circ} \mathrm{C}$ for $22 \mathrm{~h}$. Immediately after cooling, it was filtered through non-absorbent cotton wool. The filtrate was dried at $40^{\circ} \mathrm{C}$ using rotary evaporator. The amino acids in the flask were diluted with $5 \mathrm{~mL}$ of acetate buffer $(\mathrm{pH} 2.0)$ and 5 to $10 \mu \mathrm{L}$ was loaded into the cartridge of Technicon Sequential Multisample Amino acid Analyzer (TSM). The absorbance of the mixture was monitored continuously in a colorimeter, the signals were magnified and traced on a two pen recorder using a linear chart to develop a chromatograph. The area under the peak was calculated as the concentration of each amino acid.

\section{Pasting Characteristics Determination}

The pasting profile was studied using a Rapid Visco Analyser (RVA) series 4 (New Port Scientific NSW, Australia). The sample $3.0 \mathrm{~g}$ was weighed and $25 \mathrm{ml}$ of distilled water was dispensed into a canister. Paddle was placed inside the canister this was placed centrally onto the paddle coupling and then inserted into the RVA machine. The measurement cycle was initiated by pressing the motor tower of the instrument. The 12 minute profile was used. The time- temperature regime used was idle at temperature $50{ }^{\circ} \mathrm{C}$ for $1 \mathrm{~min}$., heated from $50{ }^{\circ} \mathrm{C}$ to $95{ }^{\circ} \mathrm{C}$ in $3 \mathrm{~min} .45 \mathrm{~s}$, then held at $95{ }^{\circ} \mathrm{C}$ for $2 \mathrm{~min} 30 \mathrm{~s}$ the sample was subsequently cooled to $50^{\circ} \mathrm{C}$ over $3 \mathrm{~min} 45 \mathrm{~s}$ period followed by a period of $2 \mathrm{~min}$ where the temperature was controlled at $50{ }^{\circ} \mathrm{C}$ (Anonymous, 1990). All measurements were taken in triplicate.

\section{Functional Properties determination}

The functional properties such as bulk density, water absorption capacity, swelling capacity, oil absorption capacity were determined according to the method described by Okezie and Bello (1988). Viscosity and consistency were assessed according to method described by Marero et al., (1988).

\section{RESULTS AND DISCUSSION}

\section{Physical and Malting Properties of Maize Grains}

The two maize varieties studied were white in colour. The thousand - grain weight (Table 1) of the two varieties of maize were $215.30 \mathrm{~g}$ and $271.50 \mathrm{~g} / 1000$ grains for 
Table 1. Physical and Malting properties of Quality Protein Maize and Common Maize Grains

\begin{tabular}{lcc}
\hline Parameters & Common maize & Quality Protein maize \\
\hline Colour & white & white \\
Thousand corn weight & $271.50 \pm 2.50_{\mathrm{a}}$ & $215.30 \pm 1.50_{\mathrm{b}}$ \\
$\%$ Germinative Capacity & $92.00 \pm 1.50_{\mathrm{b}}$ & $95.00 \pm 1.20_{\mathrm{a}}$ \\
$\%$ Germinative Energy & $98.00 \pm 0.50$ & $98.00 \pm 0.20$ \\
$\%$ Malt Yield & $87.60 \pm 0.50$ & $88.20 \pm 0.50$ \\
Temperature at day 1 & $29.00{ }^{\circ} \mathrm{C}$ & $28.00{ }^{0} \mathrm{C}$ \\
Temperature at day 3 & $33.00{ }^{\circ} \mathrm{C}$ & $34.00{ }^{0} \mathrm{C}$ \\
\hline
\end{tabular}

Means of the same row followed by different letters are significant $(p<0.05)$

quality protein maize and common maize respectively. The kernel of the common maize was significantly bigger $(p>0.05)$ than the quality protein maize kernel. The two varieties fall within the range of $200-300 \mathrm{mg}$ for the weight of maize kernel reported by Ihekoronye and Ngoddy (1985) and Ikujenlola (2010).

The two varieties of maize under investigation displayed high germinative energy and germinative capacity ranging between 92 and $98 \%$ respectively. The two varieties had values above $90 \%$ which is regarded as the minimum level expected of good and viable seed (Oyedoyin et al., 2001). Viability of grains depends on factors which include the moisture content, the storage condition and the effects of insect and moulds. Insect infested and mouldy grains will not be viable enough to germinate. This is important for the malting process. It was observed that there was no significant difference $(p>$ 0.05 ) in the malt yield of the two varieties of maize. The yield is affected by the lengths of the rootlets and shoots of sprouted grains, the higher the roots and shoots the less the yield of the malt (llori et al., 1990).

During the malting process there was increase in the temperature (Table 1) of the maize being malted from $29.0^{\circ} \mathrm{C}$ and $28.0{ }^{\circ} \mathrm{C}$ to $33.0^{\circ} \mathrm{C}$ and $34.0^{\circ} \mathrm{C}$ for common maize and quality protein maize respectively. The increase in temperature might be due to enzymatic activities during sprouting.

\section{Moisture content of the grains and Water uptake during steeping of maize varieties}

The moisture content of the maize grains were $12.60 \%$ and $11.11 \%$ for common maize and quality protein maize respectively. The level of moisture of the grains is often higher at harvest, but maize grains are dried so as to prolong its storage life. High moisture content during storage encourages the growth of certain harmful yeast, moulds and bacteria (Dowswell et al., 1996). Insects can cause severe losses in stored maize grain and the degree of insect damage varies according to the grain type and the texture of the kernel. The primary factors favouring insect infestation of a grain according to Dowswell et al. (1996) are availability of air (oxygen), high moisture content in air and grain and warm temperature.

The trend of water uptake of the grains over a period of 24 hours steeping is presented in Figure 1. It was observed that the moisture content of the grains increased with time of steeping. Meanwhile, at the 8 th hour of steeping the maize grains about $40 \%$ moisture had permeated the grains. Good sprouting requires that dried grains be rehydrated to about $40 \%$ moisture. The trend of the water infusion reported in this study agrees with the reports of Fashakin (1994); Gopaldas et al. (1988). Rehydrating above 8 hours turned the water slimy and milky indicative of leached starch and other nutrients from the grain.

\section{Proximate Composition of Quality Protein Maize and common Maize whole meal}

The proximate composition of the two varieties of maize is presented in Table 2. The results showed that the moisture content of the maize varieties were $7.65 \%$ and $7.90 \%$. The moisture content of grains is expected to be about $30 \%$ at harvesting and dried to between $10 \%$ and $15 \%$ for proper storage and viability. Grain of higher moisture content is highly susceptible to deterioration (Gopaldas et al., 1988).

The fat and protein contents of the quality protein maize were $4.85 \%$ and $9.72 \%$ respectively while $4.50 \%$ and $9.80 \%$ respectively were the values for common maize. There was no significantly difference $(p>0.05)$ in the crude protein of the maize varieties. According to Akumoa - Boateng (2002) and Nuss and Tanumihardjo (2011) the crude protein of QPM is not higher than that of common maize, however, it is better in terms of amino acids composition. The total ash, crude fibre and carbohydrate of quality protein maize were $1.50 \%, 2.05 \%$ and 73.98 respectively were not significantly different ( $p>0.05$ ) from $1.62 \%, 2.60 \%$ and $73.83 \%$ of common maize. 
84 Afr. J. Food Sci. Technol.

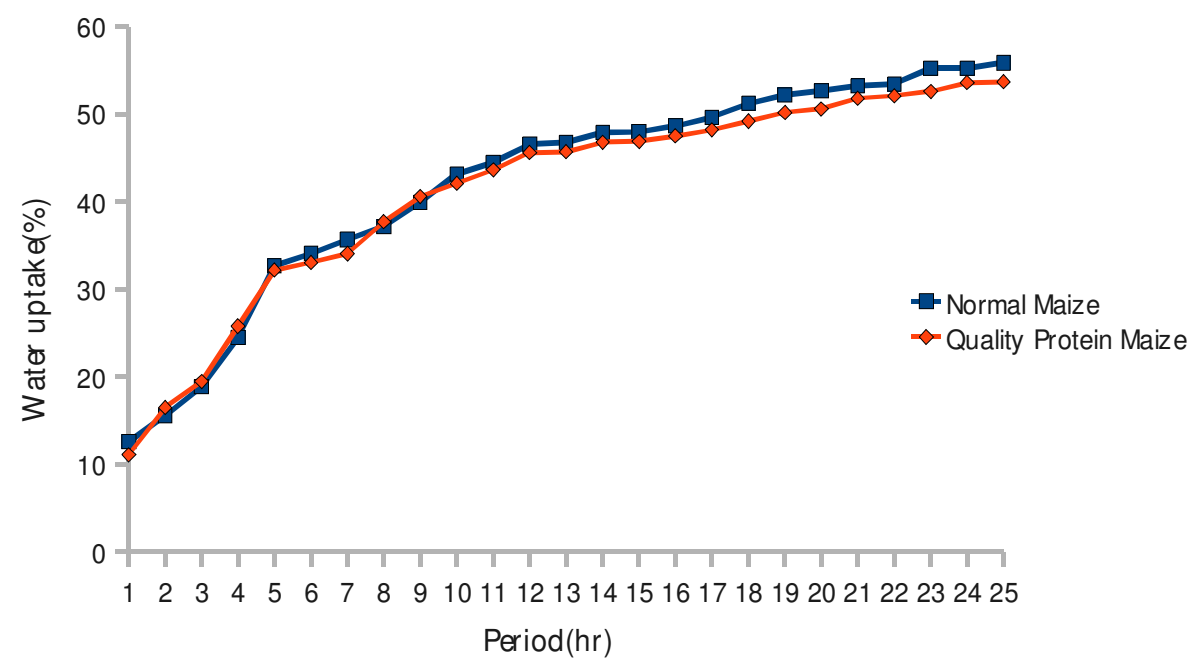

Figure 1. Water uptake of the Quality Protein Maize and Normal Maize grains

Table 2. Chemical Composition of Quality Protein Maize and Common Maize Meal

\begin{tabular}{lll}
\hline Parameter & Common Maize & Quality Protein Maize \\
\hline Moisture (\%) & $7.65 \pm 0.10$ & $7.90 \pm 0.05$ \\
Crude Fat (\%) & $4.50 \pm 0.06$ & $4.85 \pm 0.05$ \\
Crude Protein (\%) & $9.80 \pm 0.01$ & $9.72 \pm 0.12$ \\
Total Ash (\%) & $1.62 \pm 0.01$ & $1.50 \pm 0.02$ \\
Crude fibre (\%) & $2.60 \pm 0.02 \mathrm{a}$ & $2.05 \pm 0.01 \mathrm{~b}$ \\
Carbohydrate (\%) & $73.83 \pm 0.04$ & $73.98 \pm 0.04$ \\
Energy (Kcal/100g) & $375.00 \pm 0.04$ & $378.50 \pm 0.04$ \\
Sodium (mg/100g) & $61.65 \pm 10.10 \mathrm{a}$ & $43.88 \pm 2.00 \mathrm{~b}$ \\
Magnesium (mg/100g) & $141.30 \pm 5.50 \mathrm{a}$ & $137.10 \pm 4.68 \mathrm{~b}$ \\
& & \\
Potassium (mg/100g) & $77.23 \pm 3.56 \mathrm{~b}$ & $79.24 \pm 5.58 \mathrm{a}$ \\
Calcium $(\mathrm{mg} / 100 \mathrm{~g})$ & $64.70 \pm 2.34 \mathrm{~b}$ & $85.61 \pm 5.01 \mathrm{a}$ \\
Zinc $(\mathrm{mg} / 100 \mathrm{~g})$ & $11.48 \pm 1.00 \mathrm{~b}$ & $14.45 \pm 5.10 \mathrm{a}$ \\
Iron $(\mathrm{mg} / 100 \mathrm{~g})$ & $1.10 \pm 0.15$ & $0.82 \pm 0.10$ \\
Phytate $(\mathrm{mg} / 100 \mathrm{~g})$ & $1.22 \pm 0.11$ & $1.17 \pm 0.10$ \\
\hline
\end{tabular}

Means of the same row followed by different letters are significant $(p<0.05)$

The amount of calories in a quantity or volume of a food preparation is called the energy density of the food and is a good index for comparing the true value of different foods (Sajilata, 2002). There was no significant difference $(p>0.05)$ in the energy content of the two types of maize. The energy content of common and quality protein maize were 375.00 and $378.00 \mathrm{kcal}$ respectively. Maize is generally known to be high in carbohydrate and as such a good source of calories (Nuss and Tanumihardjo, 2011).

The mineral content of the samples is presented in Table 2. The result showed that the sodium $(61.65$ $\mathrm{mg} / 100 \mathrm{~g}$ ), magnesium (141.30 $\mathrm{mg} / 100 \mathrm{~g})$, iron (1.10 $\mathrm{mg} / 100 \mathrm{~g})$ of common maize were significantly higher $(\mathrm{p}<$ 


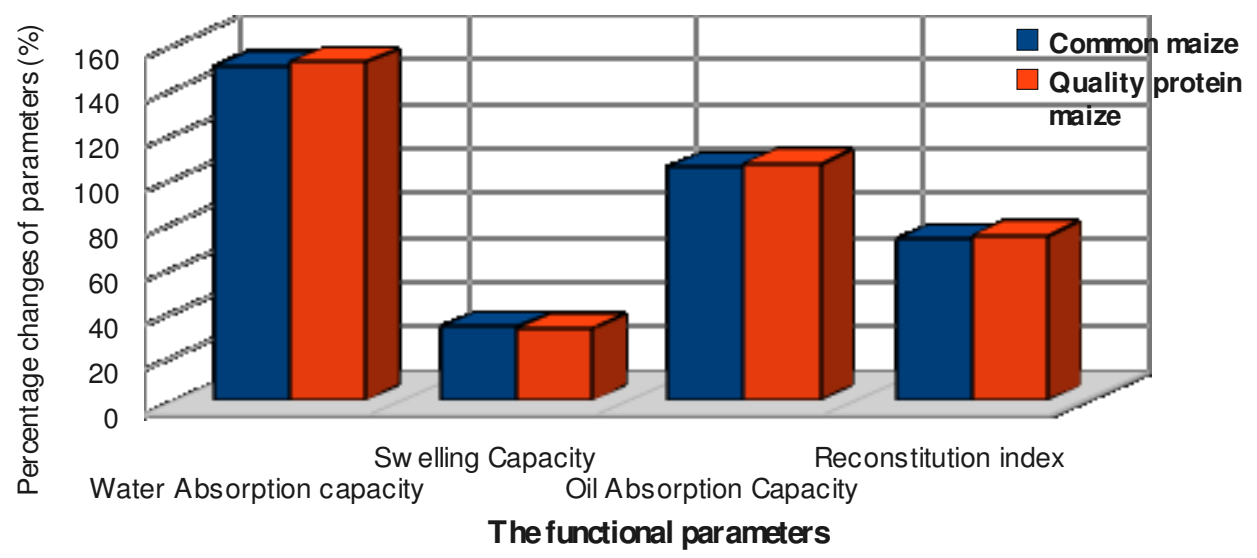

Figure 2. The Reconstitution index, Oil absorption, water absorption and swelling capacities of the two maize

0.05) than those of QPM. While the potassium (79.24 $\mathrm{mg} / 100 \mathrm{~g}$ ), calcium (85.61 $\mathrm{mg} / 100 \mathrm{~g}$ ) and zinc (14.45 $\mathrm{mg} / 100 \mathrm{~g}$ ) were higher in the QPM than common maize. All these minerals are necessary for physiological development and general well being of human being and animals. The deficiency of one or more of these mineral elements may constitute nutritional disorder in human.

The anti-nutritional factors in maize has been associated with non- bioavailability of certain minerals. Phytate in maize has been reported by FAO (1992) and Hotz and Gibson (2001) to prevent the availability of calcium to the consumer of maize and maize products. There was no significant difference $(p>0.05)$ in the level of phytate (Table 2) in the two varieties of maize. Although, antinutritional factors are responsible for non availability of certain mineral element (Annan and Plahar, 1995), on the other hand, processing such as germination, fermentation, milling and sieving have been reported as means of reducing the level and effect of antinutritional factors in cereals and legumes (Hotz and Gibson 2007; Mensah and Tomskin,2003).

\section{Functional properties of Quality protein maize and common maize whole meal}

The functional properties (Figure 2 ) of the quality protein maize oil absorption (106.00\%), water absorption $(152.00 \%)$, and swelling capacity $(32.09 \%)$ showed that there was no significant difference $(p>0.05)$ between these values and those of the common maize. However, there existed significant difference $(p<0.05)$ in the viscosities of the gruels prepared from the common maize and quality protein maize. These functional properties e.g water absorption and swelling capacity affect to a great extent the acceptability of products from grains, especially when intended for infant food. Infant food such as complementary/weaning food is expected to be high in both calories and other essential nutrients and this is achievable if the functional properties are considerably low enough to accommodate more solid per volume.

Variations in water binding capacity may be caused by inherent differences in proportion of crystalline and amorphous areas in the granules. Starches containing a higher proportion of amorphous material would presumably have more water binding sites thus absorbing more water (Lawal, 2004). The swelling behaviour of starch depends mainly on the amylose content, structure of amylose and amylopectin, and presence of non-carbohydrate substances, especially in the presence of lipids acting as inhibitor of swelling (Tester and Morrison, 1990). The swelling power is an indication of presence of amylase which influences the quantity of amylose and amylopectin present in the maize meal. The swelling power of flour granules is an indication of the extent of associative forces within the granule. Swelling power is also related to the water absorption index of the starch-based flour during heating. Therefore, the higher the swelling power, the higher the associate forces (Malomo, 2012).

The meals of the maize varieties reconstituted well to produce gruels of fine constituency during mixing. The reconstitution indices (Figure 2) of the gruels were $72 \%$ common maize and 74\% QPM. There was no significant difference $(p>0.05)$ in the values. Reconstitution index measures the ability of the flour to disperse well in the liquid medium.

In addition, the bulk density (Table 3 ) of the maize varieties were within same range of $0.70 \mathrm{~g} / \mathrm{ml}$ (QPM) and $0.71 \mathrm{~g} / \mathrm{ml}$ (common maize), The bulk density is influenced by particle size and the density of the flour and is important in determining the packaging requirement and material handling (Malomo et al., 2012). Bulk density is influenced by the structure of the starch polymers and loose structure of the starch polymers could result in low bulk density. 
86 Afr. J. Food Sci. Technol.

Table 3. Functional properties of Quality Protein Maize and Common Maize Meal

\begin{tabular}{lcc}
\hline Functional Properties & Common Maize & Quality Protein Maize \\
\hline Bulk density $(\mathrm{g} / \mathrm{ml})$ & $0.71 \pm 0.01$ & $0.70 \pm 0.01$ \\
Viscosity at $10 \%$ dry matter(cP) & $18,782.63 \pm 16.67_{\mathrm{a}}$ & $14,905.82 \pm 11.11_{\mathrm{b}}$ \\
Consistency & Semi solid & Semi solid \\
Pasting Temperature $\left({ }^{\circ} \mathrm{C}\right)$ & $79.50 \pm 0.22$ & $77.55 \pm 0.60$ \\
Peak Time (min) & $6.93 \pm 0.06_{\mathrm{a}}$ & $5.40 \pm 0.05_{\mathrm{b}}$ \\
Setback (RVU) & $283.92 \pm 0.60_{\mathrm{a}}$ & $91.75 \pm 0.25_{\mathrm{b}}$ \\
Final Viscosity (RVU) & $458.08 \pm 0.65_{\mathrm{a}}$ & $267.75 \pm 0.42_{\mathrm{b}}$ \\
Breakdown (RVU) & $113.17 \pm 0.50$ & $112.67 \pm 0.45$ \\
Trough 1(RVU) & $174.17 \pm 0.30$ & $176.00 \pm 0.23$ \\
Peak 1(RVU) & $187.33 \pm 0.20_{\mathrm{b}}$ & $288.67 \pm 0.31_{\mathrm{a}}$ \\
\hline
\end{tabular}

Means of the same row followed by different letters are significant $(p<0.05)$

\section{Pasting Properties}

The pasting properties of meals from two varieties of maize cultivars measured using RVA are presented in Table 3. When heat is applied to starch based foods in the presence of water, a series of changes occur known as gelatinisation and pasting which influence the quality and aesthetic considerations in food industry, as it affects the texture, digestibility and starchy foods (Adebowale, 2005). Meals from different cultivars displayed a significant variation in some of the pasting parameters.

The peak time and pasting temperatures of the samples showed significant differences $(p<0.05)$ in the two varieties. The peak time of common maize was 6.93 minutes while it was 5.40 minutes for QPM. The peak time is a measure of the cooking time. Meanwhile, the pasting temperatures were $79.50{ }^{\circ} \mathrm{C}$ and $77.55^{\circ} \mathrm{C}$ for common maize and QPM respectively. The pasting temperature gives an indication of the gelatinization time during processing. It is the temperature at which the first detectable increase in viscosity is measured and is an index characterised by the initial change due to the swelling (Emiola and Delarosa, 1981).

Peak viscosity (PV) of common maize and QPM meals were 187.33RVU and 288.67 RVU. Peak viscosity is an indicator of water binding capacity and ease with which the starch granules are disintegrated and often correlated with final product quality (Thomas and Atwell, 1999; Ee et al., 2014). Breakdown viscosity (BV) of the meal from different maize cultivars does not differ significantly $(p<0.05)$. Breakdown viscosity of the meals were 113.17RVU (common maize) and 112.67 RVU(QPM). The breakdown is caused by disintegration of gelatinized starch granules structure during continued stirring and heating, thus, indicating the shear thinning property of starch (Yadav et al., 2011; Babajide and
Olowe, 2013).

The trough of common maize was observed to be 174.17RVU while that of QPM was 176RVU. The minimum viscosity at constant temperature phase of the RVA profile and the ability of paste to withstand breakdown during cooling is referred to as the trough. Moreover, the final viscosity of the samples was observed to be 458.08 RVU for common maize and 267.75 RVU for QPM. In the preparation of gruel from either of these samples, the QPM sample will give gruel of low consistency and this will permit the addition of more solid. The advantage of this is that more nutrients and calories can be ensured (Marero et al.,1988)

\section{Amino Acid Profile of the Quality Protein Maize and common Maize meal}

The amino acid composition (Table 4) of the meals from both common maize and quality protein maize showed that QPM was significantly different $(p>0.05)$ from the common maize in terms of threonine $(3.20 \mathrm{~g} / 100 \mathrm{~g})$, aspartic acid $(6.76 \mathrm{~g} / 100 \mathrm{~g})$, glutamic acid $(7.50 \mathrm{~g} / 100 \mathrm{~g})$, glycine $(3.45 \mathrm{~g} / 100 \mathrm{~g})$, methionine $(1.20 \mathrm{~g} / 100 \mathrm{~g})$, isoleucine $(2.74 \mathrm{~g} / 100 \mathrm{~g})$, tyrosine $(2.73 \mathrm{~g} / 100 \mathrm{~g})$ and phenylalanine $(4.20 \mathrm{~g} / 100 \mathrm{~g})$. The level of lysine in QPM $(2.64 \mathrm{~g} / 100 \mathrm{~g})$ was significant higher $(p<0.05)$ than the level of lysine in common maize $(1.80 \mathrm{~g} / \mathrm{l00 \textrm {g }})$. This observation agrees with the report of Akumoa-Boateng (2002). This result confirms certain claims that QPM contains higher level of lysine than the common maize (Prassana et al., 2000; Akumoa- Boateng, 2002, Ikujenlola, 2010). the limiting amino acids in maize like other cereals are lysine and tryptophan, the result showed that QPM significantly contain lysine far above what was present in common maize. However, the level of tryptophan could not be determined because of the acid hydrolysis method of 
Table 4. Amino Acids of the Quality Protein Maize and common Maize

\begin{tabular}{lcc}
\hline Amino Acid & Common Maize & Quality Protein Maize \\
\hline Lysine & $1.80 \mathrm{~b}$ & $2.64 \mathrm{a}$ \\
Histidine & $2.00 \mathrm{a}$ & $2.00 \mathrm{a}$ \\
Arginine & $3.82 \mathrm{~b}$ & $4.10 \mathrm{a}$ \\
Aspartic acid & $6.21 \mathrm{~b}$ & $6.76 \mathrm{a}$ \\
Threonine & $2.00 \mathrm{~b}$ & $3.20 \mathrm{a}$ \\
Serine & $1.80 \mathrm{a}$ & $1.79 \mathrm{a}$ \\
Glutamic Acid & $5.70 \mathrm{~b}$ & $7.50 \mathrm{a}$ \\
Proline & $1.15 \mathrm{a}$ & $1.09 \mathrm{a}$ \\
Glycine & $2.50 \mathrm{~b}$ & $3.45 \mathrm{a}$ \\
Alanine & $1.7 \mathrm{~b}$ & $1.95 \mathrm{a}$ \\
Cystine & $0.70 \mathrm{~b}$ & $1.12 \mathrm{a}$ \\
Valine & $3.00 \mathrm{~b}$ & $3.60 \mathrm{a}$ \\
Methionine & 0.90 & 1.2 \\
Isoleucine & 2.53 & 2.74 \\
Leucine & $8.82 \mathrm{a}$ & $3.28 \mathrm{~b}$ \\
Tyrosine & $2.07 \mathrm{~b}$ & $2.73 \mathrm{a}$ \\
Phenylalanine & $3.50 \mathrm{~b}$ & $4.20 \mathrm{a}$ \\
\hline
\end{tabular}

Means of the same row followed by different letters are significant $(p<0.05)$

Table 5. Chemical indices of the amino acid profile of the maize varieties.

\begin{tabular}{lcc}
\hline Chemical index & Common maize & Quality protein maize \\
\hline Total amino acids & 50.20 & 63.50 \\
Essential amino acid & 26.37 & 36.96 \\
Non essential amino acid & 23.83 & 26.54 \\
Amino acid index & 63.04 & 88.35 \\
\hline
\end{tabular}

determination that was employed which destroyed the trytophan. Monogastric animal and human have difficulties in synthesising lysine from the other amino acids unlike ruminants animals. The consumption of lysine in place of common maize can bridge the gap for the monogastric animals (Zhang et al., 2012).

The Total Amino Acid (TAA) (Table 5) of QPM was 63.50 while 50.20 was the TAA of common maize. The other chemical indices of the amino acid of the grains showed that there was significant difference $(P<0.05)$ in the essential amino acid of the QPM (36.96) and common maize 26.37. Also the non essential amino acid of the maize were 26.54 QPM and 23.83 common maize. The amino acid index of the grains revealed a significant difference $(p<0.05)$ between the values for the maize varieties (88.35 QPM and 63.04 common maize). These results agree with the submission of Vassl et al., 1993 that QPM contains better usable protein than common maize and that it has protein that offers a higher biological value. Compared with traditional maize types, QPM has twice the amount of lysine and tryptophan, as well as protein bioavailability that rivals milk casein. Animal and human studies suggest that substituting QPM for common maize results in improved health. Thus, consuming QPM in place of common maize will offer better nutritional advantage. Mean while, the animal feeding experiment and human feeding trial conducted by earlier researchers show improved health (Ikujenlola, 2010; Nuss and Tanumihardjo, 2011). The utilisation of QPM in the preparation of certain family diet will offer a lot of advantages especially among the infants where maize is used as weaning food. 


\section{CONCLUSION}

This study has elicited information on the physical, chemical composition, functional properties and the amino acid composition of quality protein maize and compared with common maize. It could therefore be concluded that the chemical composition of the two varieties of maize were within the same range. However, there were differences in some of the functional properties such as viscosity, pasting time and temperature. In addition, certain amino acids of the quality protein maize were significantly higher than those of common maize especially the lysine, isoleucine, phenylalanine, methionine, glutamic acid. In view of these results QPM can be integrated into the family food where maize is used as staple and especially in the formulation of weaning food as this will help in alleviating the problem of protein energy malnutrition.

\section{REFERENCES}

A.O.A.C. (2004) Official Methods of Analysis 22nd edition.Association of Official Analytical Chemist. Washington. D.C.

Adebowale AA, Sanni LO, Awonorin SO (2005). Effect of texture modifiers on the physicochemical and sensory properties of dried fufu. Food Science and Technology International 11(5): 373-382.

Ahenkora KS, Iwurnasi -Afriyie, W. Haag, Dzah BD (1995). Ghanaian keykey from normal and Quality Protein Maize: Comparative chemical composition and rat growth trials. Cereal Research Communication 23(3):299-304

Akuamoa-Boateng A (2002). Quality Protein Maize: Infant feeding trial in Ghana, Ghana Health Service- Ashanti, Ghana. 1- 45.

Annan NT, Plahar WA (1995). Development and quality evaluation of a soy fortified Ghanaian Weaning food. Food and Nutrition Bulletin, 16(3): $263-267$

Anonymous (1990). Rapid visco analyser manual - Interpretation of Results. Newport Scientific Australia 25-28

Babajide JM, Olowe S (2013). Chemical, functional and sensory properties of water yam - cassava flour and its paste. Int. Food Res. J. 20(2): 903-909.

Bressani R (1991). Chemistry, Technology and Nutritive value of maize tortillas. Food Review International 6:225 - 264 .

Comin LM, Temelli F, Saldaña MDA (2012). Impregnation of flax oil in pregelatinized corn starch using supercritical CO2. J. Supercritical Fluids, 61:221-228. DOI: 10.1016/j.supflu.2011.08.013

Dowswell CR, Paliwal RI, Cantrell RP (1996). Maize in third World, Westview Press, New York. 1-33.

Ee SC, Jamilah B, Muhammad K, Hashim DM, Adzahan N (2014). Physico-chemical properties of spray-dried red pitaya (Hylocereus polyrhizus) peel powder during storage. Int. Food Res. J. 21(1): 155160.

Emiola L, Delarosa LC (1981). Physicochemical characteristics of yam starches. J. Food Biochem. 5: 115-130.

FAO (1992). Food and Agriculture organization: Maize in Human nutrition FAO. Rome Italy, 159- 169.

Fashakin JB (1994). Trends in weaning food. Paper presented at NIFST Western zone conference, held at Obafemi Awolowo University, Ile-Ife. $6^{\text {th }}$ May, 1994.

Gopaldas T (1988). Simple traditional methods for reducing the dietary bulk of cereal based diets in rural homes. In: Proceeding of the $20^{\text {th }}$ annual meeting of the Nutrition Society of India. Hyderabad. Nutrition Society of India 34: $73-84$.

Hotz C, Gibson RS (2001). Assessment of home based processing methods of reduces the phytate content and phytate/ Zinc ratio of white maize (Zea mays). J. Agric. Food and Chem. 49:692 - 698.

Hotz C, Gibson RS (2007). Traditional Food processing and processing and preparation practices to enhance the bioavailability of micronutrients in plants - based diet. The Journal of Nutrition.137:10971100.

Ihekoronye IA, Ngoddy PO (1985). Integrated Food Science and Technology for the tropics. Macmillan Publishing Co. London 253 257.

Ikujenlola AV (2010). Effects of malting and fermentation on the nutritional qualities of complementary foods produced from maize varieties and soybean grains. Ph.D Thesis Obafemi Awolowo University, lle- Ife, Nigeria.

Ikujenlola AV, Fashakin JB (2005). The Physico- chemical properties of a complementary diet prepared from vegetable proteins. J. Food, Agric. Environ. Finland. 3 (3): 23-26.

Ilori M, Akingbala JO, Oguntimilehin O, Ogundiwin JO (1990). Effect of grain bed thickness, duration of steeping and germination on the malting properties of improved Nigerian sorghum var. Lebensmittet Wisserschafl and Technligin 23: $505-512$.

Kaga BI, Abudullahi SA, Dynek ND (2002). Proximate Composition and amino acid profiles of two varieties of Beniseed (Sesamum indium and Sesamum radiatum) J. Agric. Technol. 10 (2) 6-10.

Kataki PK, Babu SC (2003). Food systems for improved Human Nutrition. Linking agriculture, nutrition and productivity. Haworth Press P. 193.

Lamsal BP, Wang H, Johnson LA (2011). Effect of corn preparation methods on dry-grind ethanol production by granular starch hydrolysis and partitioning of spent beer solids. Bioresource Technol.,102: 6680-6686. DOI:10.1016/j.biortech.2011.03.040.

Lawal OS (2004). Composition, physicochemical properties and retrogradation characteristics of native, oxidized, acetylated and acidthinned new cocoyam (Xanthosoma sagittifolium) starch. Food Chemistry 87: 205-218.

Maga JA (1982). Phytate: Its chemistry, occurrence, food interaction nutritional significance and method of analysis. J. of Agric. Food and Chemistry. 30: 1-9.

Malomo O, Ogunmoyela OAB, Adekoyeni OO, Jimoh O, Oluwajoba SO, Sobanwa MO (2012). Rheological and Functional Properties of SoyPoundo Yam Flour. Int. J. Food Sci. and Nutr. Eng. 2(6): 101107.DOI: $10.5923 /$ j.food.20120206.01

Marero LM, Payumo EM, Librando EC, Lainez WN, Gopez MD, Homma $S$ (1988). Technologies of weaning food formulations prepared from germinated cereals and legumes. J. Food Sci. 53:1391-5

Mburu MW, Gikonyo NK, Kenji GM, Mwasaru AM (2012). Nutritional and functional properties of a complementary food based on Kenyan amaranth grain (Amaranthus cruentus) Afr. J. Food, Agric., Nutr. Dev. Vol.12 No.2: 5959-5977

Mensah P, Tomskin A (2003). Household level technologies to improve the availability and preparation of adequate and safe complementary foods. Food and Nutrition Bulletin. 24(1): 164 -125.

Nuss ET, Tanumihardjo SA (2011). Quality Protein Maize for Africa: Closing the Protein Inadequacy Gap in Vulnerable Populations. Adv. Nutr. 2: 217-224; doi:10.3945/an.110.000182.

Okezie BO, Bello AB (1988). Physicochemical and functional properties of winged bean flour and isolate compared with soy isolate. J. Food Sci. 53:2: 450-454.

Osborne D, Voogt P (1978). The analysis of nutrients in Foods. London Academic Press. $239-245$

Oyedoyin BO, Olatunji O, Oluyide VO (2001). Malting characteristics of some newer sorghum (Sorghum bicolor) cultivars. Niger. Food J. 19: $125-131$.

Pandya TS, Srinivasan R (2012). Effect of hammer mill retention screen size on fiber separation from corn flour using the Elusieve process. Indus. Crops Products, 35: 37-43. DOI:10.116/j.indcrop.2011.06.003

Prassana BM, Vasal SK, Kassahun B, Singh NN (2001). Quality protein maize. Current Science 81 (10): 130 8- 1319.

Sajilata G, Rekha S, Singhal B, Pushpa R, Kulkarni KN (2002). Weaning Foods: A review of the Indian experience. Food and Nutrition Bulletin. 23(2): $208-226$.

Spackman DD, Stein EH, Moore S (1958). Automatic Recording Apparatus for use in the Chromatography of amino acids. Analytical Chem. 30:191-195.

Tester RF, Morrison WR (1990). Swelling and gelatinization of Cereal starches II. Waxy rice Starches. Cereal Chemistry 67(6): 551-557. 
Abiose and Ikujenlola 89

Vassal SK, Srinivasan G, Pandey S, Gonzalez FC, Crossa J, Beck DL (1993). Heterosis and combining ability of CIMMYT's quality protein maize germplasm. Crop Science 33:46-51.

Warman PR, Havard KA (1998). Yield, vitamin,mineral contents of organically conventionally grown potatoes sweet corn. Agric., Ecosyst. Environ.,68: 207-216. DOI:10.1016/S0167-8809(97)00102-3

Yadav BS, Yadav RB, Kumar M (2011). Suitability of pigeon pea and rice starches and their blends for noodle making. LWT Food Science and Technology 44: 1415-1421
Zhang B, Cui D, Liu M, Gong H, Huang Y, Han F (2012). Corn porous starch: Preparation, Characterization and adsorption property. Int. J. Biol. Macromolecules, 50 : 250-256.

DOI:10.1016/j.ijbiomac.2011.11.002

How to cite this article: Abiose S.H. and Ikujenlola A.V. (2014). Comparison of chemical composition, functional properties and amino acids composition of quality protein maize and common maize (Zea may L). Afr. J. Food Sci. Technol. 5(3):81-89 